\title{
SOSIALISASI UNDANG-UNDANG NARKOTIKA DALAM RANGKA MENYELAMATKAN GENERASI MUDA DARI BAHAYA PENYALAHGUNAAN NARKOTIKA
}

\author{
Supanto, Tika Andarasni Parwitasari, Ismunarno, Sabar Slamet, Rofikah \\ Fakultas Hukum Universitas Sebelas Maret \\ Email: supanto@staff.uns.ac.id; tika_ap@staff.uns.ac.id; ismunarno@staff.uns.ac.id; \\ sabarslamet@staff.uns.ac.id; rofikah@staff.uns.ac.id.
}

\begin{abstract}
ABSTRAK
Kegiatan pengabdian masyarakat ini adalah mensosialisasikan Undang-Undang Nomor 35 Tabun 2009 tentang Narkotika kepada para siswa Sekolah Menengah Pertama (SMP). Kegiatan ini bertujuan agarpara siswa sebagai generasi muda mengetahui dan memahami bahaya narkotika, sebingga tidak akan melakukan perbuatan yang mengarah pada tindakan terjadinya penyalahgunaan narkotika.Kegiatan pengabdian ini dilandasi pemikiran semakin maraknya penyalahgunaan narkotika di kalangan para generasi muda termasuk para siswa sekolah, baik sebagai pengguna maupun sebagai pengedar. Berdasarkan data survey Badan Narkotika Nasional tabun 2019 ada 2,3 juta pelajar di Indonesia pernab mengkonsumsi narkoba (narkotika, psikotropika, obat-obatan terlarang). Melibat data tersebut dapat dikatakan "Indonesia Darurat Narkotika”. Oleh karena itu, untuk mencegah semakin banyaknya pengguna narkoba di kalangan pelajar, maka perlu dilakukan sosialisasi bahaya penyalahgunaan narkotika. Metode kegiatan pengabdian ini berbentuk penyuluban bukum Undang-Undang Nomor 35 Tabun 2009 tentang Narkotika, yang dilanjutkan dengan dialog interaktif seputar narkoba antara para siswa dengan tim penyulub bukum yakni para Dosen Bagian Pidana Fakultas Hukum Universitas Sebelas Maret. Narkoba dari segi agama sudah pasti adalah sesuatu yang haram, dan dari segi masa depan sebuah bangsa, narkoba adalah senjata paling ampub untuk menghancurkan sebuah negara. Diharapkan dengan adanya kegiatan penyuluhan hukum ini, semakin banyak pelajar yang memiliki wawasan tentang bahaya narkoba.
\end{abstract}

Kata kunci: Undang-Undang Narkotika, narkoba, pelajar, penyuluhan bukum

\footnotetext{
ABSTRACT

This community service activity is to socialize Law Number 35 of 2009 concerning Narcotics to Junior High School students. This activity aims to make students as the younger generation know and understand the dangers of narcotics, so that they will not commit actions that lead to drug abuse. This service activity is based
} 
on the idea that narcotics abuse has become rampant among the younger generation, including school students, both as users and as dealers. Based on the Badan Narkotika Nasional survey data in 2019, 2.3 million students in Indonesia have ever consumed drugs (narcotics, psychotropic drugs, illegal drugs). Seeing the data, it can be said that Indonesia is in emergency condition of drug abuse. Therefore, to prevent the increasing number of drug users among students, it is necessary to disseminate the dangers of narcotics abuse. The method of this service activity is in the form of legal counseling on Law Number 35 of 2009 concerning Narcotics, continued with an interactive dialogue about drugs between the students and the counseling team, namely the Lecturers of the Faculty of Law, Sebelas Maret University. Drugs from a religious perspective are definitely something that is haram, and from the point of view of the future of a nation, drugs are the most powerful weapon to destroy a country. It is hoped that with this law counseling activity, more students will have an insight into the dangers of drugs.

Keywords: Law concerning narcotics, drugs, students, law counseling.

\section{PENDAHULUAN}

Peredaran dan penggunaan narkotika secara illegal akhir-akhir ini sangat marak, sudah merambah segala usia dan semua kalangan masyarakat. Mulai anak-anak, remaja, orang tua tidak jarang ditemukan mengkonsumsi narkotika secara illegal. Begitu pula kalangan para siswa di sekolah-sekolah. Indonesia darurat narkotika, itulah pernyataan yang dilontarkan oleh Badan Narkotika Nasional. Pernyataan tersebut bukan hanya isapan jempol belaka, tetapi didukung oleh data-data yang mengarah pada keadaan tersebut. Data tersebut di antaranya adalah di Kepolisian Daerah Metro Jaya tercatat pada tahun 2011 siswa SLTP pengguna narkotika sebanyak 1.345 orang, tahun 2012 meningkat menjadi 1.424 orang. Sedangkan Badan Narkotika Nasional (BNN) mencatat pada tahun 2011 penduduk Indonesia yang menggunakan narkotika berjumlah lebih kurang 4,2 juta orang, dan tahun 2015 meningkat menjadi 5,1 juta orang. Di samping itu kerugian negara akibat narkotika ini mencapai Rp 50 triliun per tahun. Pada kesempatan kuliah umum di UGM tanggal 10 Desember 2014, Presiden Jokowi menyatakan 40 - 50 orang di Indonesia mati setiap hari akibat narkotika ${ }^{1}$.

Data tersebut mengalami peningkatan, dari laman web resmi BNN melaporkan World Drugs Reports 2018 yang diterbitkan United Nations Office on Drugs and Crime (UNODC), menyebutkan sebanyak 275 juta penduduk di dunia atau 5,6\% dari penduduk dunia (usia 15-64 tahun) pernah mengonsumsi narkoba. Sementara di Indonesia, BNN selaku focal point di bidang Pencegahan dan Pemberantasan Penyalahgunaan dan Peredaran Gelap Narkoba (P4GN) mengantongi angka penyalahgunaan narkoba tahun 2017 sebanyak 3.376.115 orang pada rentang usia 10-59 tahun. Sedangkan angka penyalahgunaan Narkoba di kalangan pelajar di tahun 2018 (dari 13 ibukota provinsi di Indonesia) mencapai angka 2,29 juta orang. Salah satu kelompok masyarakat yang rawan terpapar penyalahgunaan

\footnotetext{
$1 \quad$ Republika edisi Selasa 17 Maret 2015
} 
narkoba adalah mereka yang berada pada rentang usia 15-35 tahun atau generasi milenial.

Institusi pendidikan tinggi (kampus), khususnya Fakultas Hukum UNS memiliki tanggung jawab sosial untuk turut mencegah agar pengguna narkoba di kalangan pelajar dan mahasiswa tidak semakin meningkat. Oleh karena itu, dirasa sangat perlu untuk dilakukan sosialisasi tentang bahaya penyalahgunaan narkotika. Penyalahgunaan narkotika ini oleh Undang-Undang Nomor 35 Tahun 2009 tentang Narkotika dikategorikan sebagai tindak pidana dengan kualifikasi kejahatan dan diancam sanksi pidana. Dalam Undang-Undang Narkotika ada 17 pasal yang mengatur tindak pidana narkotika dan sanksi pidananya yakni Pasal 111, Pasal 112, Pasal 113, Pasal 114, Pasal 115, Pasal 116, Pasal 117, Pasal 118, Pasal 119, Pasal 120, Pasal 121, Pasal 122, Pasal 123, Pasal 124, Pasal 125, Pasal 126, dan Pasal 129. Tindak pidana narkotika yang diatur dalam pasal-pasal tersebut meliputi pengguna, pengedar, dan produsen narkotika golongan I, II, dan III. Penggolongan narkotika ini dimuat dalam Lampiran I Undang-Undang Nomor 35 Tahun 2009 tentang Narkotika.

Ketentuan dalam Undang-Undang Narkotika ini sangat perlu untuk disosialisasikan kepada para pelajar, khususnya siswa Sekolah Menengah Pertama, agar tidak melakukan perbuatan yang mengarah pada tindakan penyalahgunaan narkotika. Siswa SMP merupakan anak-anak dengan rentang usia 12-15 tahun, dimana usia-usia tersebut masih sangat labil emosi nya, dan masih sangat mudah dipengaruhi oleh teman atau lingkungan sekitar. Kontrol diri masih sangat kurang, sehingga cenderung belum maksimal didalam menganalisa baik dan buruk nya suatu informasi ataupun peristiwa.Dr. Kartini Kartono berpendapat bahwasannya faktor penyebab terjadinya kenakalan remaja antara lain: (1) Anak kurang mendapatkan perhatian, kasih sayang dan tuntunan pendidikan orang tua, terutama bimbingan ayah, karena ayah dan ibunya masing-masing sibuk mengurusi permasalahan serta konflik batin sendiri-sendiri; (2)Kebutuhan fisik maupun psikis anak-anak remaja yang tidak terpenuhi, keinginan dan harapan anak-anak tidak bisa tersalur dengan memuaskan, atau tidak mendapatkan kompensasinya; (3) Anak tidak pernah mendapatkan latihan fisik dan mental yang sangat diperlukan untuk hidup normal, mereka tidak dibiasakan dengan disiplin dan kontrol-diri yang baik ${ }^{2}$.

SMP Muhammadiyah 2 Karanganyar, merupakan salah satu Sekolah Menengah Pertama di Kabupaten Karanganyar, berdiri di tanah seluas $4544 \mathrm{~m}^{2}$ danberalamat di Jalan Ir. Juanda, Beji, Bejen, Kabupaten Karanganyar, Jawa Tengah Kode Pos 57716. Status sekolah yang dikepalai oleh Dra. Sulastri ini adalah swasta (yayasan). SMP Muhammadiyah 2 Karanganyar mulai berdiri sejak 2 Mei 1974, kini sekolah memiliki 14 ruang kelas, satu perpustakaan dan satu laboratorium. Peserta didik berjumlah 237 orang dan 21 guru serta 4 orang tendik ${ }^{3}$. SMP Muhammadiyah 2 Karanganyar memiliki kegiatan ekstrakurikuler yang

Kartini, Kartono, Kenakalan Remaja (Jakarta: PT. Raja Grafindo Persada, 2010), 56

3 http://sekolah.data.kemdikbud.go.id/index.php/chome/profil/diakses 24 September 2020 jam 2.04 WIB 
beragam yaitu PMR, Hizbul Wathan, Futsal, Bola Voli, Seni Karawitan dan Tapak Suci. SMP Muhammadiyah 2 Karanganyar didalam mewujudkan generasi muda yang bebas dari narkoba membutuhkan pendampingan dalam hal sosialisasi produk hukum yaitu UndangUndang Nomor 35 Tahun 2009 tentang Narkotika, dan layanan konsultasi hukum tentang bahaya penyalahgunaan narkotika. Hal tersebut dimaksudkan agar para siswa memiliki wawasan tentang bahaya penggunaan narkotika, serta memiliki semangat untuk membentengi diri dari rasa ingin mencoba narkoba.

\section{METODE}

Pengabdian ini dilakukan dalam bentuk penyuluhan hukum (sosialisasi) tentang bahaya penyalahgunaan narkoba dari segi hukum yang diatur dalam Undang-Undang Nomor 35 Tahun 2009 tentang Narkotika. Selanjutnya dilakukan dialog interaktif seputar bahaya narkoba antara siswa dengan tim penyuluh yaitu dosen bagian hukum pidana Fakultas Hukum Universitas Sebelas Maret tentang upaya-upaya preventif penyalahgunaan narkoba, dan penanganan kasus-kasus penyalahgunaan narkotika. Lokasi pengabdian berjarak sekitar 14 km dari kampus Universitas Sebelas Maret yaitu di SMP Muhammadiyah 2 Karanganyar. Pada akhir kegiatan dibagikan brosur tentang narkoba yang berisi tentang pengertian dan jenis narkoba, gejala awal serta ciri fisik pengguna narkoba hingga ketentuan pidana penyalahgunaan narkoba. Kegiatan pengabdian masyarakat ini diawali dengan tahapan pertama yaitu tahap persiapan dimana tim pengabdian masyarakat melakukan observasi ke lokasi pengabdian dan melakukan wawancara mengenai permasalahan yang ada pada mitra, kemudian dilanjutkan dengan menggali informasi sejauh mana pengetahuan para siswa tentang bahaya narkoba. Tahapan kedua yaitu menyiapkan segala perangkat yang diperlukan untuk melaksanakan kegiatan pengabdian termasuk didalamnya menyiapkan materi, brosur dan sertifikat. Tahap ketiga yaitu pelaksanaan kegiatan pengabdian, berupa penyuluhan hukum dan dialog interaktif yang dilaksanakan dengan menjalankan protokol kesehatan, dikarenakan Kota Surakarta dan Kabupaten Karanganyar masih dalam status pandemi Covid19. Sasaran kegiatan penyuluhan hukum Undang-Undang Nomor 35 Tahun 2009 tentang Narkotika dalam rangka Menyelamatkan Generasi Muda dari Bahaya Penyalahgunaan Narkotika adalah para Guru dan Siswa.

\section{ANALISIS DAN PEMBAHASAN}

Pelaksanaan kegiatan sosialisasi Sosialisasi Undang-Undang Nomor 35 Tahun 2009 tentang Narkotika dalam rangka Menyelamatkan Generasi Muda dari Bahaya Penyalahgunaan Narkotika di SMP Muhammadiyah 2 Karanganyar berupa penyuluhan hukum dan dialog interaktif dilaksanakan pada tanggal 08 September 2020. Hasil dari kegiatan ini diha- 
rapkan para siswa memiliki wawasan dan kontrol diri yang baik sehingga tidak terjerumus dalam penyalahgunaan narkoba.

Kegiatan penyuluhan hukum diawali dengan menjelaskan pengertian narkotika dan penggolongan narkotika. Narkotika adalah zat atau obat yang berasal dari tanaman atau bukan tanaman, baik sintetis maupun semisintetis, yang dapat menyebabkan penurunan atau perubahan kesadaran, bilangnya rasa, mengurangi sampai menghilangkan rasa nyeri, dan dapat menimbulkan ketergantungan, yang dibedakan ke dalam golongan-golongan sebagaimana terlampir dalam Undang-Undang ini.

Penyalahgunaan narkotika di Indonesia telah sampai pada titik yang sangatmemprihatinkan danmembahayakan dengan sasaran yang telah menyentuh seluruh lapisan masyarakatNarkotika digolongkan ke dalam ${ }^{5}$ :

a. Narkotika golongan I, adalah narkotika yang hanya dapat digunakan untuk tujuan pengembangan ilmu pengetahuan dan tidak digunakan dalam terapi, serta mempunyai potensi sangat tinggi mengakibatkan ketergantungan.

b. Narkotika golongan II, adalah narkotika berkhasiat pengobatan digunakan sebagai pilihan terakhir dan dapat digunakan dalam terapi dan/atau untuk tujuan pengembangan ilmu pengetahuan serta mempunyai potensi tinggi mengakibatkan ketergantungan.

c. Narkotika golongan III, adalah narkotika berkhasiat pengobatan dan banyak digunakan dalam terapi dan/atau untuk tujuan pengembangan ilmu pengetahuan serta mempunyai potensi ringan mengakibatkan ketergantungan.

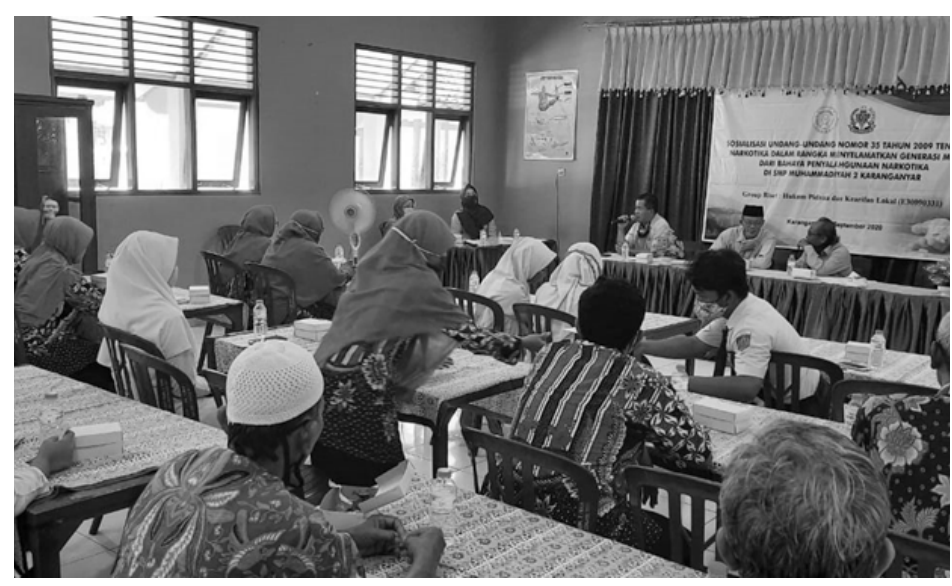

Pasal 1 Undang-Undang Nomor 35 Tahun 2009 tentang Narkotika.

5 Pasal 6 Undang-Undang Nomor 35 Tahun 2009 tentang Narkotika dan Penjelasannya. 
Penjelasan dilanjutkan dengan pemaparan Undang-Undang Narkotika yang berlaku saat ini adalah untuk mewujudkan masyarakat adil dan makmur dengan cara ${ }^{6}$ :

a. Meningkatkan derajat sumber daya manusia Indonesia guna mewujudkan kesejahteraan rakyat perlu dilakukan upaya peningkatan pengobatan dan pelayanan kesehatan, antara lain dengan mengusahakan ketersediaan narkotika jenis tertentu yang dibutuhkan sebagai obat, serta melakukan pencegahan dan pemberantasan bahaya penyalahgunaan dan peredaran gelap narkotika dan prekusor narkotika. Rumusan ini karena narkotika di satu sisi merupakan obat atau bahan yang bermanfaat di bidang pengobatan atau pelayanan kesehatan, pengembangan ilmu pengetahuan dan di sisi lain dapat pula menimbulkan ketergantungan yang sangat merugikan apabila disalahgunakan tanpa pengendalian yang ketat dan seksama.

b. Mengintegrasikan antara pendekatan hukum dan pendekatan kesehatan yang mengatur upaya di bidang hukum dan upaya di bidang kesehatan secara seimbang dalam menangani kejahatan penyalahgunaan narkotika. Membagi kejahatan penyalahgunaan narkotika menjadi dua kelompok yaitu kelompok penyalahguna dan kelompok pengedar dengan menyiapkan dua sistem penanganan yaitu terhadap kelompok penyalahguna melalui sistem peradilan rehabilitasi dan terhadap kelompok pengedar melalui sistem peradilan pidana.

c. Mengatur peredaran narkotika secara legal untuk kepentingan kesehatan, ilmu pengetahuan dan teknologi menyangkut seluruh aspek produksi, distribusi dan konsumen diatur secara ketat dan seksama, jika bertentangan dengan peraturan perundang-undangan merupakan tindak pidana narkotika.

d. Mendorong penegak hukum untuk meningkatkan profesionalisme dalam melaksanakan tugas karena peredaran narkotika bersifat transnasional menggunakan modus operandi tinggi, teknologi canggih didukung jaringan organisasi yang luas dan penyalahgunanya diberikan hukuman rehabilitasi.

Anang Iskandar, Penegakan Hukum Narkotika (Jakarta : PT. Elex Media Komputindo, 2019), 28-29. 


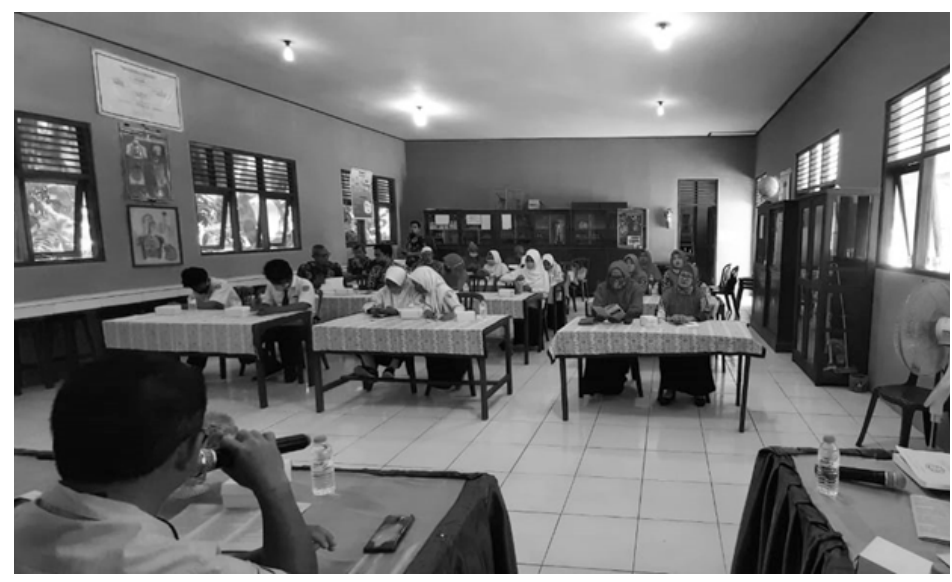

Tim Penyuluh menyampaikan segala aspek hukum terkait penyalahgunaan narkotika, dan juga memberikan motivasi kepada para siswa agar menghindari narkotika dengan cara menjaga diri dengan keimanan dan ketakwaan, selektif dalam pergaulan, menerapkan pola hidup sehat, berpikir jangka panjang, dan sebisa mungkin mengisi waktu luang dengan kegiatan yang bermanfaat. Masalah narkoba merupakan masalah rumit, bukan sekedar masalah generasi muda yang kecanduan saja, namun lebih dari itu, bahwa masalah narkoba juga merupakan masalah kejahatan yang ditumpangi kegiatan bisnis, perdagangan, ekonomi dan juga keuangan. Masalah narkoba lekat dengan masalah kelemahan dalam penegakan hukum, dan penanganan terhadap komprador. Lebih berbahaya lagi, masalah narkoba adalah masalah rongrongan terhadap pertahanan dan keamanan dan ancaman terhadap kedaulatan bangsa dan negara. Tegasnya, didalam perdagangan narkoba terselip misi penaklukan untuk mencerabut kedaulatan suatu bangsa. Inilah bisnis yang selain bertujuan meraup keuntungan laba besar dan sekaligus menimbulkan kelumpuhan bangsa.

Kepala Badan Narkotika Nasional (BNN) Komjen Budi Waseso mengatakan narkoba dijadikan sebagai barang bisnis pencari keuntungn dan kekayaan. Bandar narkoba adalah musuh bersama, pengkhianat bangsa. Merekalah orang-orang yang menghendaki kehancuran Indonesia. Lebih lanjut narkoba juga digunakan sebagai senjata khusus untuk melumpuhkan suatu negara. Narkotika merupakan kejahatan luar biasa yang mengancam dunia, dan bisa digunakan sebagai salah satu senjata dalam proxy war untuk melumpuhkan kekuatan suatu bangsa, karenanya masalah narkotika harus ditangani secara komprehensif. Indonesia masih menjadi salah satu target gempuran narkotika, karena memiliki lahan atau pasar terbesar bagi peredaran narkotika. Indonesia adalah pasar yang besar bagi para gembong narkotika. Indonesia dijadikan target kelinci percobaan penaklukan dengan merusak secara massal generasi penerus Indonesia. Jaringan ini menyasar anak-anak siswa SD, SMP, SMA dan mahasiswa serta generasi muda Indonesia pada umumnya. Peredaran gelap narkoba tidak melulu masalah bisnis, tapi ditengarai ada upaya yang sistematis untuk secara mental 
dan moral-psikologis menghancurkan generasi muda bangsa Indonesia. Narkoba kerap dijadikan proxy war atau perang tanpa bentuk untuk melumpuhkan kekuatan suatu bangsa ${ }^{7}$.

Dalam mengkaji permasalahan penanggulangan penyalahgunaan narkotika yang dilakukan oleh pelajar, dapat dipahami sebagai salah satu bentuk kebijakan atau upaya penanggulangan kejahatan (criminal policy) yang pada hakekatnya merupakan bagian integral dari upaya perlindungan masyarakat (social defence) dan upaya mencapai kesejahteraan masyarakat (social welfare). Oleh karena itu dapat dikatakan bahwa tujuan utama dari politik kriminal ialah perlindungan masyarakat untuk mencapai kesejahteraan masyarakat ${ }^{8}$. Politik kriminal atau kebijakan penanggulangan kejahatan bila dilihat ruang lingkupnya, sangat luas dan tinggi kompleksitasnya. Hal ini dikarenakan, pada hakekatnya kejahatan merupakan masalah kemanusiaan dan sekaligus masalah sosial yang memerlukan pemahaman tersendiri. Kejahatan sebagai masalah sosial merupakan gejala yang dinamis, selalu tumbuh dan terkait dengan gejala dan struktur kemasyarakatan lainnya yang sangat kompleks yang merupakan social political problems. Dengan demikian, maka pemahaman akan hubungan antara perkembangan kejahatan dengan perkembangan struktur masyarakat dengan segala aspeknya baik sosial, ekonomi, politik, budaya, merupakan suatu kebutuhan yang sangat penting bagi usaha penanggulangan kejahatan, termasuk terhadap kejahatan narkotika?

Secara umum, kegiatan pengabdian masyarakat di SMP Muhammadiyah 2 Karanganyar berjalan dengan lancar, acara dihadiri oleh para guru dan perwakilan siswa. Semua yang hadir mendengarkan penjelasan yang diberikan dengan sungguh-sungguh, dan sangat antusias dalam mengikuti dialog interaktif. Di akhir acara dibagikan brosur mengenai informasi-informasi penting seputar penyalahgunaan narkotika beserta pertolongan pertama dari dampak penggunaan narkoba. Para siswa juga diberikan pemantapan pemahaman tentang haram nya narkoba melalui beberapa ayat dalam Al Qur'an yaitu Surah Al A'raf Ayat 157"Dan menghalalkan bagi mereka segala yang baik dan mengharamkan bagi mereka segala yang buruk"; Surah Al Baqarah 195 "Dan janganlah kamu menjatubkan dirimu sendiri ke dalam kebinasaan."; Surah An Nisa Ayat 29 "Dan janganlah kamu membunuh dirimu, sesunggubnya Allah adalab Maha Penyayang kepadamu.”. Ayat - ayat tersebut menunjukkan haramnya merusak atau membinasakan diri sendiri, narkoba sudah pasti memberikan dampak negatif terhadap tubuh dan akal seseorang. Mengonsumsi narkoba tentu menjadi sebab yang bisa mengantarkan pada kebinasaan karena narkoba hampir sama halnya dengan racun.

Bambang Abimanyu, Perang Narkoba di Indonesia (Jakarta:Indonesia Press, 2019), 335-339.

8 Barda Nawawi Arief, Kebijakan Legislatif dalam Penanggulangan Kejahatan dengan Pidana Penjara (Semarang: Ananta, 1994), 11.

9 Kusno Adi, Kebijakan Kriminal dalam Penanggulangan Tindak Pidana Narkotika oleh Anak (Malang: UMM Press, 2009), 24. 


\section{KESIMPULAN}

Kegiatan pengabdian masyarakat berupa Sosialisasi Undang-Undang Nomor 35 Tahun 2009 tentang Narkotika dalam rangka menyelamatkan generasi muda dari bahaya penyalahgunaan narkotika di SMP Muhammadiyah 2 Karanganyar sangat membantu pihak sekolah dalam memberikan wawasan dan motivasi kepada para siswa untuk senantiasa waspada dan menghindari narkoba. Penyuluhan hukum tentang narkotika diharapkan dapat menjadi benteng diri para siswa untuk menjauhi narkoba, dan tidak sekalipun ingin mencobanya. Kegiatan penyuluhan hukum ini, akan dilakukan dengan lebih intens dan dilanjutkan dengan kegiatan konsultasi.

\section{DAFTAR PUSTAKA}

Anang Iskandar. (2019). Penegakan Hukum Narkotika. Jakarta: PT. Elex Media Komputindo. Bambang Abimanyu. (2019). Perang Narkoba di Indonesia. Jakarta: Indonesia Press.

Barda Nawawi Arief. (1994). Kebijakan Legislatif dalam Penanggulangan Kejahatan dengan Pidana Penjara. Semarang: Ananta.

Kartini, Kartono. (2010). Kenakalan Remaja. Jakarta: PT. Raja Grafindo Persada.

Kusno Adi. (2009). Kebijakan Kriminal dalam Penanggulangan Tindak Pidana Narkotika oleh Anak. Malang: UMM Press.

Undang-Undang Nomor 35 Tahun 2009 tentang Narkotika. 